\title{
Health promotion to people with disabilities: case report from two University extension projects
}

\author{
Promoção da saúde às pessoas com deficiência: relato de duas experiências de extensão \\ universitária \\ Promoción de la salud para personas con discapacidad: informe de dos experiencias de extensión \\ universitária
}

Ana Claudia Camargo Gonçalves Germani ORCID: https://orcid.org/0000-0002-7409-915X

Universidade de São Paulo, Brazil

E-mail: ana.germani@fm.usp.br

Fabiana Gonçalves de Mello Cahú ORCID: https://orcid.org/0000-0002-1692-5337 Centro Universitário Maurício de Nassau, Brazil E-mail: fabianacahu@hotmail.com

Fellipe Eugênio Soares Miranda ORCID: https://orcid.org/0000-0002-1181-4929 Centro Universitário Maurício de Nassau, Brazil

E-mail: fellipesoaresmiranda@gmail.com

Fernanda Géa de Lucena Gomes ORCID: https://orcid.org/0000-0002-9587-4717 Instituto Remo meu Rumo, Brazil E-mail: fernandaglucena@gmail.com

Patricia Moreno Grangeiro ORCID: https://orcid.org/0000-0002-1533-659X Hospital das Clínicas da Faculdade de Medicina da Universidade de São Paulo, Brazil E-mail: patricia.moreno@hc.fm.usp.br Ana Carolina Basso Schmitt ORCID: https://orcid.org/0000-0003-3685-6735 Universidade de São Paulo, Brazil E-mail: carolinaschmitt@usp.br

Alfredo Almeida Pina-Oliveira
ORCID: https://orcid.org/0000-0002-1777-4673
Centro Universitário Campo Limpo Paulista, Brazil
E-mail: alfredo.oliveira@ faccamp.br

\begin{abstract}
Developing Health Promotion programs and interventions for people with disabilities during undergraduate health courses represents a relevant strategy to ensure comprehensive, equitable and universal care. Objective: to describe and reflect on two Brazilian experiences focused on promoting the health of people with physical disabilities within the scope of university extension. Method: this is the report of experiences derived from the "Praia Sem Barreiras" Project in Recife (PE) and the "Remo Meu Rumo" Project in São Paulo (SP), Brazil. Results: both activities are interdisciplinary, interprofessional and intersectoral. They focus on relationships between Higher Education Institutions and articulate community partnerships focusing on well-being, self-care and physical activity and leisure. Final Considerations: it is evident that the performance of undergraduate health students and professors excelled in the use of public spaces in the city as a powerful strategy for social inclusion, collaborative learning and the exercise of citizenship. However, it is necessary to broaden the discussion on developing Health Promotion skills to prepare the health sector workforce with greater sensitivity to the needs of people with disabilities or reduced mobility.
\end{abstract}

Keywords: Students, health occupations; Disabled persons; Health promotion; Community-institutional relations.

\section{Resumo}

Desenvolver programas e intervenções de Promoção da Saúde para pessoas com deficiência durante a graduação em saúde representa uma estratégia relevante para a garantia do cuidado integral, equitativo e universal. Objetivo: descrever e refletir sobre duas experiências brasileiras voltadas para promover a saúde de pessoas com deficiência física no âmbito da extensão universitária. Método: trata-se do relato das experiências derivadas do Projeto Praia Sem Barreiras em Recife (PE) e do Projeto Remo meu Rumo em São Paulo (SP). Resultados: ambas as atividades são 
interdisciplinares, interprofissionais e intersetoriais baseadas nas relações entre Instituições de Ensino Superior e articulam parcerias comunitárias com foco no bem-estar, no autocuidado e na atividade física e de lazer. Considerações Finais: evidencia-se que a atuação dos estudantes de graduação em saúde e dos docentes primou pela utilização de espaços públicos da cidade como estratégia potente para a inclusão social, a aprendizagem colaborativa e o exercício da cidadania. Todavia, há a necessidade de ampliar a discussão sobre como desenvolver as competências de Promoção da Saúde para preparar uma força de trabalho com maior sensibilidade às necessidades das pessoas com deficiência física e ou mobilidade reduzida.

Palavras-chave: Estudantes de ciências da saúde; Pessoas com deficiência; Promoção da saúde; Relações comunidade-instituição.

\section{Resumen}

El desarrollo de programas e intervenciones de Promoción de la Salud para personas con discapacidad durante los cursos de pregrado en salud representa una estrategia relevante para asegurar una atención integral, equitativa y universal. Objetivo: describir y reflexionar sobre dos experiencias brasileñas dirigidas a promoción de la salud de personas con discapacidad física en el ámbito de la extensión universitaria. Método: se realizo un informe de experiencias derivadas del Proyecto Praia Sem Barreiras en Recife (PE) y el Proyecto Remo Meu Rumo en São Paulo (SP). Resultados: ambas actividades son interdisciplinarias, interprofesionales e intersectoriales basadas en las relaciones entre Instituciones de Educación Superior y articulan alianzas comunitarias con foco en el bienestar, el autocuidado y las actividades físicas y de ocio. Consideraciones finales: es evidente que el desempeño de los estudiantes y profesores de salud de pregrado se destacó en el uso de los espacios públicos de la ciudad como una poderosa estrategia para la inclusión social, el aprendizaje colaborativo y el ejercicio de la ciudadanía. Sin embargo, es necesario ampliar la discusión sobre cómo desarrollar habilidades de Promoción de la Salud para preparar a la fuerza laboral del sector de la salud con mayor sensibilidad a las necesidades de las personas con discapacidad o mobilidad reducida.

Palabras clave: Estudiantes del área de la salud; Personas con discapacidad; Promoción de la salud; Relaciones comunidad-institución.

\section{Introduction}

The World report on disability estimates that more than a billion people today experience disability (WHO, 2011). Therefore, integrating disability topics into undergraduate formation must be strategic to achieve WHO report recommendations to provide healthcare workers with effective responses to health needs.

The training of health professionals should recognize the human rights approach for disabled persons (Shakespeare, 2009) and must explore innovative educational interventions for health care professionals (Shakespeare, 2013).

However, Health Promotion (HP) for people with disabilities has been neglected as an area of interest (Rimer, 1999 e Harrison, 2006) and sometimes mentioned solely as primary prevention or restricted to discussions in the health sector.

There are examples involving learning programs for specific behaviors as a physical activity focused on people with physical disabilities (Bassett-Guntere et al., 2019). Nevertheless, HP teaching and learning initiatives are incipient. One compelling example addresses health disparities at the intersection of disability, race, and ethnicity in a Master of Public Health program where HP is one of the topics covered (Onyeabor, 2016).

Fortunately, in the Shanghai Declaration (2017), there were orientations to moving ahead with the 2030 Agenda and, in particular, three items converge to issues related to people with disabilities: leaving no one behind, and also ensuring and protecting people's rights - no matter their position in society, gender, sexual orientation, age or level of disability and keeping a strong focus on the local - and cities as a robust platform.

Health promotion for people with disabilities faces more challenges on the practical than on theory grounds. A systematic review on Health Promotion for People with Disabilities analyzed 14 studies and observed that the most investigated subject was public policies and services, followed by accessibility (Interdonato \& Greguol, 2011).

As an important aside, health promoters and educators should be aware of various disabilities (physical, cognitive, visual, hearing loss, and multiple disabilities) and different impacts on developing health policies and practices (Reichard et al., 2015). This article focuses on physical disabilities such as paraplegia, tetraplegia, spinal muscular atrophy, and limb 
amputation.

Another aspect of introducing even in a concise way is the concept of the environment as "the complex, integrated, and overlapping social structures and economic systems that are responsible for most health inequities. These social structures and economic systems include the social environment, physical environment, health services, and structural and societal factors" (Hammel, 2015).

The International Classification of Functioning, Disability and Health (ICF) has a specific topic for environmental factors and pointed out that "Environmental factors are to be coded from the perspective of the person whose situation is being described" and classified them in five items: 1. products and technology; 2. natural environment and human-made changes to the environment, 3. support and relationships; 4. attitudes and 5. services, systems and policies.

A recent recommendation is to teach the International Classification of Functioning, Disability and Health to enhance a biopsychosocial approach to care (Scholten, 2021).

However, practical aspects of health promotion for people with disabilities have been poorly investigated (Interdonato \& Greguol, 2011). Therefore, this paper aims to describe and reflect on two Brazilian experiences focused on promoting the health of people with physical disabilities within the scope of university extension.

\section{Methodology}

This paper is a descriptive-exploratory study based on two cases report. They are community experiences cases that could support teaching practices (Pereira et al., 2020). Furthermore, it sounds like an innovative way to introduce disability and health issues for health professionals following other international initiatives (Rogers et al., 2016).

Initially, we present a brief description of the Brazilian context and a reflection on two experiences. After that, a balance between experiences, learnings and recommendations to improve health promotion to people with physical disabilities, acknowledging the importance of territorial inclusion to crossing networks. In the end, we discuss how to teach and learn HP with them as "the essential voice in matters of its health, living conditions and wellbeing", according to the Ottawa Chapter previously recommended.

\section{Results and Discussion}

We describe two HP experiences involving people with physical disabilities to improve leisure-time physical activity (LTPA), social inclusion and citizenship. They occur in two different natural environments - a beach in Recife and the Olympic rowing course in Sao Paulo. Both activities explore the natural environment as a space or place for interaction and socialisation among people with disabilities and health care undergraduate students.

\section{Local Context}

Brazil is the largest country in South America and Latin America, the World's fifth-largest and sixth-most populous country, composed of 26 states and the Federal District. It covers an area of 8,515,767 square kilometres with a population of over 211 million, and in 2010, 6,7\% of people with disabilities, visual impairment being the most common, affecting $3.4 \%$ of the population, followed by the motor $(2.3 \%)$, mental/intellectual $(1.4 \%)$ and hearing impairment present in $1.1 \%$ of the population (IBGE,2018).

Since 2008, Brazil has had a National Health Policy Program for people with disabilities that encompasses quality of life promotion, disability prevention, comprehensive care to health, improvement of information mechanisms, human resources training, and the organisation and functioning of services. 
In parallel, there is a local particularity in Higher Education recommendations. For example, in one of the Brazilian regulatory frameworks of higher education (Resolução 2018), there is an explicit mention of University Extension as well translated as Community-Institutional Relations. It means the interactions between several stakeholders such as community members, governmental or non-governmental representatives and Higher Education faculty or students.

According to the National Policy of this Community-Institutional Relations, this activity used to be an "interdisciplinary, political, educational, cultural, scientific, technological process, which promotes the transformative interaction between higher education institutions and other sectors of society. Both experiences happen in two urban cities and involve two sorts of Higher Education Institutions (HEI) (Figure 1).

Figure 1. Two experiences focus on health promotion to and within people with disabilities in Brazil, 2019.

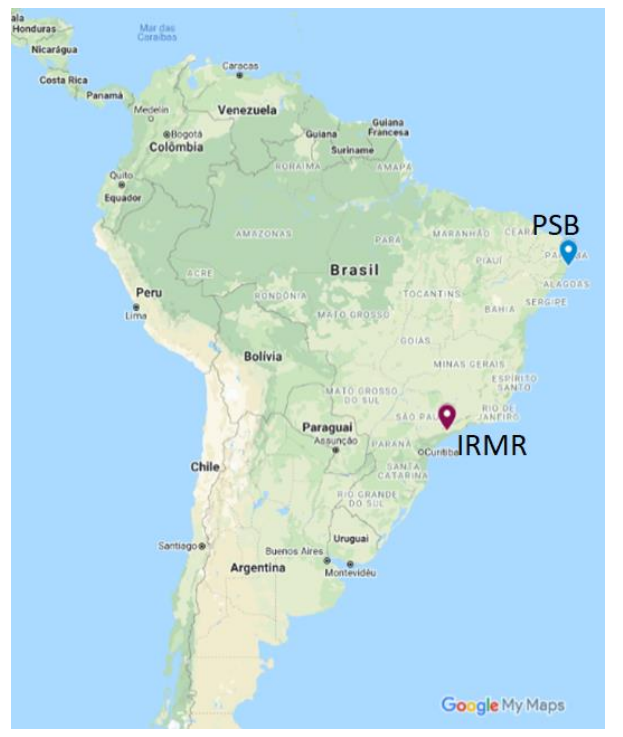

Source: Google Maps; the authors indicate Praia Sem Barreiras Project in blue location icon and Remo Meu Rumo Project in red location icon.

Recife is the largest urban area of the North/Northeast Regions of Brazil, and it is the capital of Pernambuco. The Centro Universitário Maurício de Nassau (UNINASSAU) is a private college. Its mission is to prepare competent citizens and qualified professionals to act with social responsibility and improve national social-economic development.

UNINASSAU provides professionals and students to support the Praia sem Barreiras (PSB) Project at Boa Viagem beach. The staff participates in practical workshops regarding caring for people with physical disabilities or reduced mobility, theoretical training about the project's functioning, interpersonal relations, the supervisors' guidance and the students' roles in the PSB.

São Paulo is a municipality in the Southeast Region of Brazil and the most populous city in Brazil, the Americas, the Western Hemisphere and the Southern Hemisphere. The University of São Paulo (Universidade de São Paulo, USP, in Portuguese) is the largest Brazilian public university, as well the most prestigious educational institution. It excels the entanglement among teaching, research and university extension in all areas of knowledge, offering a broad range of courses.

The Remo meu Rumo (RMR) Project consists of a teaching-learning experience in an extension activity on a sports complex designed for rowing and canoeing at the Raia Olímpica, parallel to the Pinheiros River waterfront. 


\section{Description and Reflection about the two experiences \\ Praia Sem Barreiras Project}

Inaugurated in March 2013, the Praia Sem Barreiras (PSB) Project is part of the Accessible Tourism program and strives for the leisure, wellbeing and social inclusion of people with physical disabilities and reduced mobility. Its main activities are the assisted-bathing service, adaptive sports, recreation programs and socialization opportunities.

The PSB represents an agreement among the Pernambuco State Government, Recife City Hall and Centro Universitário Maurício de Nassau (UNINASSAU). It happens from Friday to Sunday, from 8:00 am to 12:00 pm. This project has the infrastructure of one tent, three thirty-meter mats that allow more effortless locomotion on the beach sand, twelve amphibious wheelchairs that allow the user to access the assisted bathing performed by the students. There is also a leisure area with a seated volleyball court and two pools of a thousand litres for children or elders. When the sea is not in safe or favorable conditions, those pools allow alternative activities with the main participants of PSB.

In addition to the structure set up on the beach, the Recife City Hall defined an accessible route on the shore to serve this specific public: a bus stop closes to the PSB, a specific parking space, and an accessible pedestrian path to the tents and the seashore.

The UNINASSAU faculty from health undergraduate courses runs PSB and recruits regularly undergraduate students of Physical Education, Physiotherapy, Nursing and Tourism.

Their participation is voluntary and grants a scholarship. However, selected students must engage in practical training on the routine and duties as monitors. In 2019, at the time of this comparative analysis, they had ten health care students.

Teachers who manage all actions in PSB receive the title of supervisor. They increase knowledge, develop skills, and stimulate ethical attitudes to assist persons with disabilities or reduced mobility in a beach setting to assure safety and leisure and utilise assistive technologies or adaptative activities.

Students insertion takes six months, and its renewal could occur with their supervisors' endorsement. According to the project coordination, the students most interested in the project are those from the health care course, specifically Physiotherapy, Nursing and Physical Education.

\section{Remo Meu Rumo Project}

The São Paulo Olympic Rowing Course is an artificial body of water out of groundwater built-in 1972 for the Pan American Games, as the rivers in São Paulo were no longer navigable. It is located inside the main campus of the University of São Paulo and is a unique environment representing an ecosystem with clean water, many fish, birds, trees and capybaras.

Exercising in a place so full of nature promotes real feelings of wellbeing. Practicing rowing and canoeing provides gains in strength, physical conditioning and skills, and experiences such as a feeling of freedom, confidence and independence since our participants depend only on themselves to move the boat. In the water activity, the results of the interventions converge.

In rowing boats and kayaks, participants put into practice their strength and balance skills and working in groups, thus experiencing the values of our sport.

Remo Meu Rumo Institute (IRMR) emerged from the mission of facilitating inclusion through sports for children and adolescents with cerebral palsy and other motor impairments. Its main goal is to enable the adapted practice of rowing and canoeing to promote physical, psychological and social development.

The scarcity of structures and opportunities for young people to practice sports motivates the Remo meu Rumo (RMR) Project.

In a brief historical review of the RMR, health professionals were concerned with children and adolescents with 
physical disabilities cared at the Institute of Orthopedics and Traumatology pediatric ward, Hospital das Clínicas, Medical School, University of São Paulo (IOT-HCFMUSP). Hence, they should benefit from physical activity and leisure in their postoperative care and Physiotherapy treatments.

Thus, rehabilitation could be more comprehensive and pleasant if these youngsters could transition from the medicalhospital environment to USP Rowing Course and develop their physical capacities through adapted sports.

Physical therapy and physical education professionals help improve the function, conditioning and fitness of RMR participants. In addition, psychologists and social workers guide full human development and citizenship. The integrated work of this interprofessional health team is the backbone of IRMR.

Activities happen from Mondays to Thursdays in two periods, morning and afternoon, and on Saturdays in the morning. With accessibility infrastructure, the initiative offers adapted equipment and boats to the participants' needs and motor limitations.

The RMR focus on their participants' capacities and not their disability when rowing a rowboat or a kayak. Therefore, activities take place in three environments:

- The boat garage-headquarters, where participants do conditioning training, practice with other gym equipment to develop strength and balance, undergo functional assessments with the health team professionals, train on the rowing ergometer and have initial contact with the sport.

- The water tank, where they practice the technical aspects of the sport and make it possible to understand the adaptations that each participant will need when rowing on the boats.

- Water activities, where the results of interventions converge.

In rowboats and kayaks, participants put into practice their strength and balance skills, in addition to being able to explore the environment autonomously.

The IRMR allow physical education, physical therapy and medicine undergraduate students to complement their professional training both in practice and in the academic area, participating in workshops, joining various courses and supporting the interprofessional teams in their daily activities.

In addition, these students can participate either in a paid internship (though Federal Resources for Sports Projects after the evaluation of student's curricula from different universities) or through an internship based on an academic partnership with the Physical Education and Sports School USP.

At the start of their activities at RMR, every student receives the "Intern's Manual". It standardizes the information regarding the Internship Program at the IRMR and presents the institution's objectives and good practices.

They also receive theoretical and practical training, both general (knowledge about different diseases and disabilities) and specific (e.g., technical teachers of rowing and canoeing guide physical education students or physical therapists advise Physiotherapy students).

Learning experiences include educational initiatives (such as life support courses) and weekly talks, case presentations and discussions. Additionally, daily discussions through WhatsApp stimulate clinical thinking and put theoretical concepts into their practices.

Besides professional development, students can partake in the agenda of IRMR. Thus, they participate in outside events such as visitation to corporations to provide social and vocational experiences, workshops on activities to develop motor abilities, gatherings to help the health team promote social and leisure activities for IRMR participants. In sum, these opportunities contribute to students' creativity and innovation skills.

As children, teenagers, and young people assisted by the IRMR learn sports values such as confidence, independence, autonomy, motivation, and others, interns and students similarly feel confident interacting with people with disabilities and 
their families and colleagues and students and volunteers. They will carry on these experiences and be ahead of their peers in professional attitude and soft skills in their professional life.

In a quick survey with 30 volunteers about how the IRMR promotes health, it was meaningful to find concepts such as functioning and quality of life, empowerment and family engagement.

The IRMR contributes so that the most vulnerable populations, unable to pay for rowing and canoeing classes, can enjoy the experience of these sports and, in this way, collaborates with the state in its duty to offer activities that allow the participation and protagonism of people with disabilities in sports activities. In 2020, IRMR had its registration approved by the Municipal Council of Rights of Children and Adolescents (CMDCA) and accreditation in the National Support Program for Health Care of the Person with Disability (PRONAS/PCD).

\section{Balance between experiences, learnings and recommendations}

The two experiences reported in this article start from the local environment and advance in health promotion strategies that consider and explore the specificities of spaces/places to create health promotion actions focusing on LTPA and crossing networks. The authors believe that they are initial experiences to the advance in health promotion to people with disabilities.

This kind of community-based education intervention about disability is not usual in Higher Education Institutions (HEI) in Brazil and across the World (Shakespeare. 2013). At the same time, it seems an opportunity for health care students to have meaningful interactions with disabled people. In addition, literature evidence shows a positive change in communication skills (Andersen, 2011) and positive attitudes towards persons with physical disabilities who had more experience (Satchidanand et al., 2012).

Besides their local particularities, it is essential to highlight the similarities in these two University Extension Projects related to promote the health of disabled persons:

- Both are interdisciplinary, considering that both experiences put together different knowledge;

- They promote opportunities for interprofessional education and collaborative practices as they bring together students, teachers, and health professionals with different backgrounds focused on health promotion to people with disabilities or motor limitations.

- They are intersectoral putting together the Higher Education Institution, Health Care workers and transport policy in Recife and a Non-Government Organization and Health Care workers in São Paulo.

- Given that disability is complex and multi-faceted, unique challenges must be addressed to provide comprehensive care. Consequently, interaction and collaborative practice are imperative since:

"Collaborative practice in healthcare occurs when multiple health workers from different professional backgrounds provide comprehensive services by working with patients, their families, carers and communities to deliver the highest quality of care across settings". (WHO, 2010)

Terminology and language is one sensitive issue for collaborative practices focusing on the care of disabled persons. The Disability Attitude Implicit Association Test (DA-IAT) addresses the differences between the experience versus beliefs to recognise the attitudes toward people with disabilities (Pruett, 2006).

Even though most healthcare providers indicate having nothing against people with disabilities, the overwhelming majority display implicitly prejudices towards this specific public (VanPuymbrouck, 2020).

The two cases reported promoting an introductory talk about prejudice, stereotyping, and discrimination in healthcare undergraduate courses. The educators and students should pay attention to expressions and attitudes that could be microaggressions, defined as "subtle forms of discrimination and include verbal, nonverbal, or environmental slights that 
convey disparaging messages to people based upon their group membership, such as disability." (Lee, 2019). This concept was used initially for racial issues, extending to other minorities (Olkin, 2019). Listening and learning with them is the best way to recognise and assure good communication and assertive caring.

The second recommendation discusses implementing the best practices in teaching-learning for accessibility, health advocacy and social inclusion. The disabled person should act as an expert to teach the students how to deal with this condition (Shakespeare, 2013).

At Praia sem barreiras (PSB) e Remo meu Rumo (RMR), these exchanges are eventual and not part of pedagogical strategies or curricula. Nevertheless, the people with disabilities are the essential voice in their health, living conditions and wellbeing (as the Ottawa Chapter recommended).

The experiences described an initial and punctual movement towards teaching-learning HP in unique scenarios: natural settings. However, educators must acknowledge that a 'spiral of learning' approach enables a longitudinal exposition (Shakespeare, 2013).

Challenges and questions to open a necessary discussion:

- How to approach promoting the health of people with disabilities in their current academic or professional practices?

-What is the local reality concerning the number of people with disabilities?

How does reality's local environments (natural and artificial) facilitate or hinder the health promotion of people with disabilities?

- What opportunities could include this theme?

-Who could approach and engage in the community, educational institutions, faculty, and students?

- What kind of environments could explore to discuss HP for and within people with disabilities?

- How to develop global and local frameworks for closing the gap in the availability of health promotion programs and interventions for people with disabilities?

- How facilitate the inclusion of people with disabilities in these and other health promotion programs?

\section{Final Considerations}

Considering that it is appropriate to underpin ethical, equitable and comprehensive (and collaborative) care to people with disabilities, the authors gather some recommendations.

First, we reinforce a call to action for Higher Education Institutions representatives to create conditions and opportunities to guarantee an undergraduate experience based on Human Rights knowledge, principles, skills and values.

The Health Promotion of people with disabilities or reduced mobility depicts an inclusive and respectful scenario to teaching and learning in natural settings like beaches, rivers, and other public spaces. The two cases reported reinforcing the social relevance of territories appropriation, citizenship and cultural belonging.

Thus, we encourage other researchers, professors and stakeholders to describe their experiences and evaluate projects that involve teaching, research and extension in an inseparable way and their effects on the health promotion of people with different types of disabilities.

The last landmark consists of preparing a more sensitized and prepared healthcare workforce, which could assure HP for people with disabilities. Reflections upon the PSB and RMR experiences may contribute to further discussions and moments to develop Health Promotion Competencies focusing on the people with physical disabilities or reduced mobility needs. 


\section{Acknowledgments}

We thank Tuca Munhoz for valuable discussions and reflections regarding disabled person rights, accessibility, and urban mobility.

\section{References}

Anderson, E. S., Ford, J. \& Thorpe, L. (2011) Learning to listen: improving students' communication with disabled people. Medical Teacher 33 (1), $44-52$. https://doi.org/10.3109/0142159X.2010.498491

Bassett-Gunter, R., Angevaare, K., Tomasone, J., Leo, J., Varughese, B., Langvee, J., \& Ginis, K. M. (2019). A systematic scoping review: resources targeting the training and education of health and recreation practitioners to support physical activity among people with physical disabilities. Disability and health journal, 12(4), 542-550. https://doi.org/10.1016/j.dhjo.2019.06.007

Belo, A. Z. A. V., \& Mendes, M. I. B. de S. (2019). Percepção de corpos com deficiência física: um estudo sobre o Projeto Praia Sem Barreiras em Recife-PE. Revista Brasileira de Educação Física e Esporte, 33(4), 587-596. https://doi.org/10.11606/issn.1981-4690.v33i4p587-596

Belo, A. Z. V. A., \& Mendes, M. I. B. de S. (2017). Être à la plage dans un fauteuil: un nouveau corps propre. Recherches \& Educations, (HS), $153-167$. Retrieved from https://journals.openedition.org/rechercheseducations/2867

Brasil. Departamento de Ações Programáticas Estratégicas, Secretaria de Atenção à Saúde, Ministério da Saúde. (2008). Política Nacional de Saúde da Pessoa com Deficiência. Recuperado de: https://bvsms.saude.gov.br/bvs/publicacoes/politica_nacional_saude_pessoa_deficiencia.pdf

Brasil. Ministério da Educação. Resolução no 7, de 18 de dezembro de 2018 que Estabelece as Diretrizes para a Extensão na Educação Superior Brasileira e regimenta o disposto na Meta 12.7 da Lei $n^{\circ}$ 13.005/2014, que aprova o Plano Nacional de Educação - PNE 2014-2024 e dá outras providências, p. 1-12, 2018.

Demográfico, IBGE-Censo. "Releitura dos dados de pessoas com deficiência no Censo Demográfico 2010 à luz das recomendações do Grupo de Washington." Nota técnica 1 (2010): 2018. https://ftp.ibge.gov.br/Censos/Censo_Demografico_2010/metodologia/notas_tecnicas/nota_tecnica_2018_01_censo2010.pdf

Hammel, J., et al. (2015). Environmental barriers and supports to everyday participation: a qualitative insider perspective from people with disabilities. Archives of physical medicine and rehabilitation 96(4), 578-588. https://doi.org/10.1016/j.apmr.2014.12.008

Harrison, T. (2006). Health promotion for persons with disabilities: what does the literature reveal? Family \& community health, 29(1), 12S-19S

Interdonato, G. C., \& Greguol, M. (2011). Promoção da Saúde de Pessoas com Deficiência-uma revisão sistemática. HU Revista, 37(3).

Kim, J., Kim, J., Kim, Y., Han, A., \& Nguyen, M. C. (2021). The contribution of physical and social activity participation to social support and happiness among people with physical disabilities. Disability and Health Journal, 14(1), 100974. https://doi.org/10.1016/j.dhjo.2020.100974

Lee, E. J., Ditchman, N., Thomas, J., \& Tsen, J. (2019). Microaggressions experienced by people with multiple sclerosis in the workplace: An exploratory study using Sue's taxonomy. Rehabilitation psychology, 64(2), 17. https://doi.org/10.1037/rep0000269

Olkin, R., Hayward, H. S., Abbene, M. S., \& VanHeel, G. (2019). The experiences of microaggressions against women with visible and invisible disabilities. Journal of Social Issues, 75(3), 757-785. https://doi.org/10.1111/josi.12342.

Onyeabor, S. (2015). Addressing Health Disparities at the Intersection of Disability, Race, and Ethnicity: the Need for Culturally and Linguistically Appropriate Training for Healthcare Professionals. Journal of Racial and Ethnic Health Disparities, 3(3), 389-393. https://doi.org/10.1007/s40615-015-01409.

Pereira, B. H. P., Rodrigues, J. M., dos Anjos, A. A., Takahashi, C. H. T., Etgeton, M., Toyama, R. Y., \& de Lima Simch, F. B. (2020). Abordagem lúdica na promoção da saúde a idosos institucionalizados-um relato de experiência. Research, Society and Development, 9(11), e569119497-e569119497. https://doi.org/10.33448/rsd-v9i11.9497

Pina-Oliveira, A.A., Amaral Silva, M., Conceição da Silva, V., Miranda, F. E. S., \& Cahú, F. G. M. (2020). Análise hemerográfica da promoção da saúde na divulgação on-line do projeto "Praia sem Barreiras." Revista Conexão UEPG, 16, 1-12. https://doi.org/10.5212/rev.conexao.v.16.14424.031.

Pruett, S. R., \& Chan, F. (2006). The development and psychometric validation of the Disability Attitude Implicit Association Test. Rehabilitation Psychology, 51(3), 202. https://doi.org/10.1037/0090-5550.51.3.202

Reichard, A., Stransky, M., Phillips, K., Drum, C., \& McClain, M. (2015). Does type of disability matter to public health policy and practice? Californian Journal of Health Promotion, 13(2), 25-36. https://doi.org/10.32398/cjhp.v13i2.1821

Rimmer, J. H. (1999). Health promotion for people with disabilities: the emerging paradigm shift from disability prevention to prevention of secondary conditions. Physical therapy, 79(5), 495-502. https://doi.org/10.1093/ptj/79.5.495

Rimmer, J. H., Vanderbom, K. A., Bandini, L. G., Drum, C. E., Luken, K., Suarez-Balcazar, Y., \& Graham, I. D. (2014). GRAIDs: a framework for closing the gap in the availability of health promotion programs and interventions for people with disabilities. Implementation Science, 9(1), 1-9. https://doi.org/10.1186/s13012-014-0100-5

Rogers, J. M., Morris, M. A., Hook, C. C., \& Havyer, R. D. (2016). Introduction to disability and health for preclinical medical students: didactic and disability panel discussion. MedEdPORTAL, 12. https://doi.org/10.15766/mep_2374-8265.10429 
Research, Society and Development, v. 11, n. 1, e56111124956, 2022

(CC BY 4.0) | ISSN 2525-3409 | DOI: http://dx.doi.org/10.33448/rsd-v11i1.24956

Satchidanand, N., Gunukula, S. K., Lam, W. Y., McGuigan, D., New, I., Symons, A. B., \& Akl, E. A. (2012). Attitudes of healthcare students and professionals toward patients with physical disability: a systematic review. American Journal of Physical Medicine \& Rehabilitation, 91(6), 533-545. 10.1097/PHM.0b013e3182555ea4

Scholten, I., Barradell, S., Bickford, J., \& Moran, M. (2021). Twelve tips for teaching the International Classification of Functioning, Disability and Health with a view to enhancing a biopsychosocial approach to care. Medical Teacher, 43(3), 293-299. https://doi.org/10.1080/0142159X.2020.1789082

Shakespeare, T., \& Kleine, I. (2013). Educating health professionals about disability: a review of interventions. Health and Social Care Education, 2(2), 2037. https://doi.org/10.11120/hsce.2013.00026

Shakespeare, T., Iezzoni, L. I., \& Groce, N. E. (2009). Disability and the training of health professionals. The Lancet, 374(9704), 1815-1816. https://doi.org/10.1016/S0140-6736(09)62050-X

VanPuymbrouck, L., Friedman, C., \& Feldner, H. (2020). Explicit and implicit disability attitudes of healthcare providers. Rehabilitation psychology, 65(2), 101. http://dx.doi.org/10.1037/rep0000317

World Health Organization. (2011). World report on disability 2011. World Health Organization. https://www.who.int/disabilities/world_report/2011/report.pdf

World Health Organization. (2017). Promoting health: Guide to national implementation of the Shanghai Declaration. Geneva: World Health Organization; 2017 (WHO/NMH/PND/18.2). Recuperado de: https://www.who.int/publications/i/item/WHO-NMH-PND-18.2

World Health Organization. International Classification of Functioning, Disability and Health. Geneva.2002. 